\title{
Penerapan "Civic Journalism" PR FM Dalam Membangun Iklim Demokrasi di Jawa Barat
}

\author{
Roni Tabroni \\ Fakultas Ilmu Komunikasi dan Administrasi, Universitas Sangga Buana YPKP Bandung \\ E-Mail: roni_tepas@yahoo.com
}

\begin{abstract}
Abstrak: Civic journalism merupakan salah satu konsep jurnalistik yang berupaya untuk membangun partisipasi publik dalam proses demokrasi melalui saluran media massa. Penelitian ini bertujuan menggali civic journalism yang diterapkan PR FM di Jawa Barat dengan konsep civic journalism. Penelitian ini menggunakan metode studi kasus dengan teknik pengumpulan data berupa wawancara mendalam dan observasi. Penelitian ini menemukan upaya PR FM dalam membangun civic journalism dengan konsep citizen journalism sejak awal berdirinya. PR FM sejak awal terus mengampanyekan pentingnya keterlibatan publik. Awalnya, PR FM memberikan contoh, sekarang keterlibatan itu sangat tingi, sampai banyak persoalan publik yang mampu diselesaikan. Uniknya, PR FM mampu menjadi sahabat dekat pendengar dengan menjadi tempat curhat urusan pribadi. Di sini, PR FM dengan cerdas memosisikan diri sebagai jembatan informasi yang aktif untuk mengarahkan setiap konten dan aspirasi yang masuk.
\end{abstract}

Kata kunci: PR FM, civic journalism, partisipasi publik

\begin{abstract}
Civic journalism is one concepts of journalism that seeks to build public participation in the democratic process through mass media channels. This research aims to explore the civic journalism applied by PR FM in West Java with the concept of civic journalism. This study uses a case study method with data collection techniques in the form of in-depth interviews and observations. This study found the efforts of PR FM in building civic journalism with the concept of citizen journalism has been starting since its inception. PR FM from the beginning continued to campaign the importance of public involvement. Initially, PR FM gave an example, now that involvement is very high, so many public problems has resolved. Uniquely, PR FM is able to become a close friend to the listeners by becoming a place to sharing personal matters. PR FM intelligently positions itself as an active information bridge to direct every incoming content and aspiration.
\end{abstract}

Keywords: PR FM, civil journalism, public participation 


\section{PENDAHULUAN}

Pers di Indonesia sejak awal kehadirannya sudah memberikan kontribusi yang cukup baik. Sejak zaman penjajahan, perjuangan, bahkan di beberapa era, pers selalu memiliki posisi pentingnya, sehingga tidak bisa dipisahkan dari pembangunan demokrasi di tanah air. Tidak ada yang bisa menyangkal bahwa partisipasi pers dalam pembangunan dari waktu ke waktu begitu penting (Soegito, 1981).

Walaupun pers pada beberapa kepemimpinan Nasional mengalami tekanan dari mulai yang biasa-biasa hingga pembredelan, tetapi tetap konsisten hadir untuk memberikan kontribusinya. Dari mulai Orde Lama hingga Orde Baru, pers sering kali mendapat hambatan, sebagiannya lagi bahkan sampai dimatikan, tetapi itu bukan berarti peran pers menjadi tidak penting. Kondisi seperti itu justru semakin menunjukkan betapa strategisnya pers di tengah situasi sosial dan politik yang ada (Hill, 2011).

Radio sebagai lembaga pers memiliki peran sangat strategis dalam membangun sebuah daerah. Dengan peran dan fungsinya, radio pun dapat menjadi salah satu instrumen untuk mendukung pemerintah dalam segala bidang. Walaupun demikian, di dalamnya radio juga memiliki fungsi kritik sosial yang tidak bisa dipisahkan darinya (Keith, 2000a).

Sebagaimana media cetak (koran, majalah, dan tabloiod) dan juga televisi dan online, radio tidak hadir di ruang hampa. Sistem pers dari media massa sangat dipengaruhi oleh sistem politik di sebuah negara atau daerah tersebut. Di tengah dinamika politik dan sosial yang terjadi, radio senantiasa hadir mewarnai setiap perjalanannya. Di sini, radio dibutuhkan bukan hanya untuk hiburan, tetapi juga untuk saluran informasi. Bahkan, jika melirik dari aspek kesejarahannya, radio di Indonesia sangat lekat dengan perjuangan kemerdekaan atau sebagai alat perjuangan.

Dalam menjalankan perannya di masyarakat, di tanah air radio begitu identik dengan dunia hiburan (Keith, 2000b). Di dalamnya banyak konten yang memanjakan telinga, acara-acaranya dominan lagu dan perbincanganperbincangan ringan. Maka, tidak heran jika sejak lama radio diminati juga karena di dalamnya ada acara dongeng. Para pendengarnya begitu luas dan massif, karena radio memanjakan masyarakat lewat fungsi hiburan itu (Keith, 2000c).

Namun, seiring perkembangan kebutuhan masyarakat akan informasi, maka lahir beberapa radio yang bernuansa informasi. Radio-radio tersebut selalu menyampaikan berita secara periodik, walaupun prosentase hiburannya cukup tinggi. Pasca reformasi, kita melihat fenomena yang lebih maju, di mana radio kemudian sebagiannya bergeser ke arah news. Selain beberapa radio yang berdiri sendiri, juga ada radio news yang berafiliasi dengan media cetak - atau pengembangan dari media cetak.

Radio yang berbasis pada berita ini membawa nuansa baru di dunia radio yang asalnya identik dengan hiburan. Dahulu, ketika orang membutuhkan informasi yang lebih serius pasti larinya ke media cetak, kemudian ke televisi (itu pun hanya waktu-waktu tertentu). Namun kini, radio sudah menjadi bagian dari sumber informasi publik yang patut diperhitungkan. Terlebih, radio-radio tersebut tidak lagi menjadikan berita sebagai selingan, tetapi keseluruhan siaranya adalah berita (Keith, 2000d).

Radio berbasis news ini dari sisi jumlah tidak banyak. Walaupun dinilai nekad, menjadi radio berita bagi sebagiannya justru strategis. Strategis karena radio berita masih sangat jarang (bahkan tahun 1990 belum ditemukan). Yang menarik kemudian bagaimana konsep berita yang dipilih oleh berita 
berbasis news ini. Sebagian radio ada yang menjadikannya sebagai media konvensional, yaitu menyampaikan berita seperti halnya media cetak atau televisi. Radio menjadi saluran informasi atas berbagai peristiwa yang terjadi di lapangan. Reporter melakukan liputan secara langsung di lapangan, kemudian melakukan on air. Dengan demikian radio itu sudah menyiarkan berita secara baik. Cara kerja lainnya adalah melakukan scrip writer terhadap naskah-naskah berita yang berasal dari berbagai media lainnya, baik cetak maupun online.

Radio hanya menyampaikan informasi begitu saja, tanpa ada target yang lebih selain hanya ingin agar masyarakat menjadi tahu dari sesuatu yang sebelumnya tidak tahu. Fungsi edukasi hanya memenuhi aspek informasi saja, tanpa melibatkan publik dalam proses pembuatan beritanya. Lebih tepatnya, publik hanya menjadi pendengar pasif, tidak ada kesempatan berbagi informasi.

Fungsi yang lebih berani dilakukan radio terkait dengan kontrol sosial. Radio selalu menyoroti berbagai persoalan publik, termasuk kebijakan pemerintah. Hanya saja, apa yang dilakukan dalam proses kritik sosial bersifat sepihak. Artinya, radio menjadi lembaga tunggal yang mengkritisi berbagai persoalan, tanpa peduli apakah kritiknya itu efektif atau tidak. Termasuk apakah publik senang atau tidak dengan cara mengkritik seperti itu.

Dalam pergeseran fungsi media saat ini, radio sebenarnya tidak bisa berdiri sendiri, khususnya dalam menjalankan fungsi kritik sosialnya. Media tidak lagi menjadi seperti anjing penggonggong yang tidak memiliki fungsi apa pun selain memunculkan kegaduhan di kalangan masyarakat. Kini media, juga radio senantiasa melibatkan publik dalam menyelesaikan berbagai persoalan sosial. Media dapat menjadi pihak yang mengajak kepada pendengarkan untuk melakukan gerakan-gerakan nyata terhadap berbagai masalah yang dirasakan bersama. Inilah yang dalam dunia jurnalisme disebut dengan civic jurnalism, ketika media (dalam hal ini radio) menjadikan pendengarnya sebagai partner dalam menjalankan fungsi-fungsi sosialnya. Radio bukanlah institusi yang sangat hebat dan mampu menyelesaikan berbagai perpsoalan sendirian. Sebab, kritik saja buktinya tidak mampu menyelesaikan masalah, dibutuhkan tindakan nyata.

Karena radio bukanlah institusi yang paling tahu tentang berbagai hal, maka metode yang digunakan radio untuk memperkaya informasi yaitu dengan menggunakan citizen journalism. Citizen journalism di sini merupakan salah satu strategi untuk membangun kesadaran publik agar mau berbagi informasi, bahkan saling memberikan masukan terhadap berbagai peristiwa yang terjadi.

Kebersamaan antara redaksi dengan publik untuk senantiasa berbagi kabar merupakan langkah maju agar masyarakat selain dapat informasi juga sekaligus memiliki kemauan dan keberanian membagi informasi secara cuma-cuma. Laporan-laporan khas masyarakat ini menjadi keunikan tersendiri, sebab kebanyakan publik tidak memiliki kaidah jurnalistik khususnya tata bahasa dan pengolahan kata-kata ketika membagi informasi apapun.

Di Jawa Barat, salah satu radio yang menggunakan pola citizen journalism dengan pendekatan partisipasi masyarakat dalam membagi kabarnya yaitu PR FM. Yaitu sebuah stasiun radio yang memilih untuk menjadi radio berbasis berita dengan melibatkan masyarakat dalam menyelesaikan berbagai persoalan yang terjadi. PR FM memposisikan diri sebagai fasilitator yang siap menampung seluruh informasi yang disampaikan, keluhan publik, temuan, bahkan kekesalan. PR FM di sini kemudian membagi lagi kepada 
publik lain untuk turut serta memberikan solusi terhadap persoalan yang ada yang dikemukakan pendengar sebelumnya. Pada kasus-kasus tertentu yang memerlukan penanganan atau jawaban dari pihak pemerintah misalnya, PR FM secara langsung meneruskannya kepada pihak yang berwenang, atau langsung mengontaknya dan berinteraksi dengan orang yang menyampaikan masalah tadi.

\section{METODE}

Metode yang diambil dalam penelitian ini adalah studi kasus dengan teknik pengumpulan data berupa wawancara mendalam dan observasi. Stake dan Creswell, menyatakan bahwa studi kasus merupakan penelitian yang akan menjelaskan strategi penyelidikan dimana peneliti mengeksplorasi secara mendalam sebuah program, acara, kegiatan, proses atau satu atau lebih individu. Dalam penelitian ini, yang menjadi subjek penelitian adalah PR FM yang mengangkat civic journalism dengan pola pelibatan masyarakat dapam proses liputannya.

Studi kasus dilakukan untuk menganalisis sebuah kegiatan siaran di PR FM yang dianggap unik dan memiliki kelebihan dibanding media berbasis berita lainnya. Kekhassan PR FM dalam melibatkan masyarakat untuk membangun iklim demokrasi dianggap unik sebab dapat menjadi solusi untuk berbagai persoalan yang terjadi di masyarakat.

Creswell juga menjelaskan bahwa penelitian studi kasus ini merupakan multisource atau merupakan studi dengan banyak sumber. Terkait dengan pemilihan informan dalam penelitian kualitatif, Creswell menyatakan bahwa dalam penelitian kualitatif penentuan informan dilakukan secara purposive sesuai dengan karakteristik informan yang disesuaikan dengan kebutuhan penelitian.

\section{Civic Journalism}

Civic jorunalism merupakan gagasan yang mengintegrasikan atnara jurnalisme ke dalam proses demokrasi. Media dalam civic journalism bukan hanya menginformasikan kepada publik, tetapi juga dapat bekerjasama dengan warga negara untuk menciptakan wacana yang sehat sekaligus untuk melakukan gerakan produktif dalam konteks demokrasi (Rosen, 2001).

Civic journalism menghentikan cara berpikir bahwa wartawan dan masyarakat merupakan objek yang terpisah dalamkehidupan sosial dan politik yang terjadi, bahkan cenderung posisinya sebagai penonton belaka. Lebih dari itu, civic journalism kemudian menjadikan wartawan dan masyarakat sebagai peserta aktif, ke dua-duanya dapat menjadi aktor perubahan di sebuah daerah atau negara. Kehadiran civic journalism tidak hanya menjadi wacana tentang konsep belaka tetapi merupakan gerakan nyata sehingga menimbulkan efek signifikan dalam proses pembangunan.

Civic journalism pada dsaranya dikembangkan oleh wartawan profesional menyikapi meningkatnya ketidakpercayaan publik terhadap media dan kesinisan publik terhadap politik Amerika Serikat sekitar tahun 1988 (Kurniawan, 2007). Kondisi ini merupakan kritik yang sangat serius terhadap kondisi media massa yang cenderung arogan, sehingga civic journalism mengajak kita untuk berfikir kembali tentang nilai sebuah berita, berikut fungsi dan peran media massa di masyarakat.

Untuk itu, Rosen dan Park sebagaimana dikutip Rachmiatie (2005) menjelaskan tentang civicjournalism yang diartikan sebagai suatu model peliputan berita yang bertujuan sesuai dengan misi negara yakni mendorong kehidupan publik atau warga negaranya menuju kesejahteraan dan mencari konsensus 
untuk memecahkan permasalahan yang terjadi di masyarakat.

Mempraktekkan Civic journalism berangkat dari sebuah perangkat nilai yang kemudian dikembangkan dalam praktek, sehingga keduanya menjadi sebuah aktivitas jurnalisme. Jurnalisme hadir di tengah situasi sosial tertentu, tidak berada di ruang hampa, sehingga jurnalisme memiliki kewajiban terhadap kehidupan publik. Civic journalism tidak hanya menjadi wadah untuk lalu lintasnya sebuah informasi atau peristiwa, tetapi jurnalisme turut mempengaruhi dan berkontribusi secara kongkrit (Pew Center for Civic Journalism).

Untuk itu Glasser memandang civic journalism sebagai: pertama, setiap orang dapat berbicara dalam konteks urusan bukti, posisinya bukan sebagai objek atau korban tetapi sebagai warga negara yang aktif. Kedua, membantu masyarakat politik untuk bertidak dan bukan hanya belajar tentang sesuatu. Ketiga, turut serta dalam memperbaiki iklim wacana publik, bukan hanya cukup mengeluh dengan kondisi yang semakin tidak baik. Keempat, turut serta membantu untuk memperbaiki kehidupan semakin baik sehingga setiap orang akan mendapat pengakuan. Kelima, dituntut untuk senantiasa berbicara jujur mengenai berbagai nilai warganegara, tentang pandangan politik, serta keberadaan perannya di masyarakat (Glasser, 1999).

Dengan ilustrasi yang cukup menarik, Merrit misalnya mengibaratkan jurnalis di dalam Civic journalism seperti pihak ketiga, yang jika dalam olah raga disebut wasit. Posisi wasit bukanlah orang yang membuat peraturan, sebab aturan sudah disepakati oleh masingmasing warga negara dalam menentukan apa yang harus dilakukannya. Wasit yang jelas harus adil, sebab mereka adalah pihak yang menjadi penentu sebuah lalu lintas wacana itu sukses atau tidak, sebab di sini warga negara bukan lagi objek tetapi peserta aktif dalam proses demokrasi. Maka apa yang harus dimiliki oleh jurnalis adalah jiwa di mana mereka berada dalam kehidupa publik yang memiliki pengetahuan dan peraturan, di mana sebuah demokrasi harus berjalan dengan baik. Warga negara akan menentukan sebuah kesepakatan tentang sebuah informasi yang akan mendukung proses demokratisasi dan mereka memiliki hak untuk didengarkan dan difasilitasi (Merritt, 1998).

Dvorkin (2011), menjelaskan bahwa Civic journalism merupakan serangkaian nilai tentang keterampilan yang dapat memadukan antara jurnalisme dengan demokrasi. Nilai yang dimaksud adalah menghormati posisi warga negara sebagai subjek dalam politik, yang memiliki hak untuk menyampaikan aspirasinya termasuk aktor-aktornya dan mereka bukanlah sebagi objek atau korban. Di sini, media massa memerankan Civic journalism sebagai bentuk kepedulian sehingga senantiasa dapat menyelesaikan masalah publik dengan mendorong keterlibatannya dalam proses jurnalisme.

Dalammenjalankancivic journalism menurut David K. Perry (2003), seorang praktisi civic journalism sebaiknya berpegang pada prinsip utamanya, seperti: pertama, memposisikan media sebagai peserta aktif dalam kehidupan kemasyarakatan, bukan hanya sebagai penonton yang pasif. Kedua, menjadikan media sebagai sarana untuk berdiskusi tentang isu-isu masyarakat. Ketiga, lebih mementingkan persoalan dan isu-isu bagi orang biasa. Keempat, memposisikan opini publik sebagai proses diskusi dan debat antar anggota masyarakat. Kelima, menjadikan jurnalis ebagai pihak yang dapat meningkatkan modal sosial.

Jika civic journalism dimaksudkan untuk membangun partisipasi publik dalam rangka demokratisasi, maka diperlukan metode bagaimana agar publik turut terlibat dalam proses jurnalismenya. 
Salah satu yang dianggap efektif dan mudah untuk dilakukan publik dalam proses partisipasi ini adalah citizen journalism. Di sini publik tidak hanya menjadi konsumen, tetapi secara teknis turut terlibat dalam proses pelaporan berita, termasuk menyampaikan aspirasinya.

Citizen journalism atau jurnalisme warga menurut Kusnadi (2006), merupakan kegiatan dimana peran wartawan atau kegiatan jurnalistik biasa dilakukan oleh masyarakat yang secara formal bukan wartawan. Kegiatan ini yang dilakukannya sama dengan wartawan pada umumnya, yakni mengumpulkan informasi, menulis berita, mengedit dan menyiarkannya. Awalnya banyak pihak menganggap citizen journalism sebagai ancaman bagi wartawan profesional, namun dalam perkembangannya, pola ini justru menjadi peluang dalam membangun dunia jurnalisme yang lebih baik. Para jurnalis warga justru dapat memberikan informasi awal yang beragam yang tidak terjangkau oleh wartawan profesional, informasi tersebut kemudian menjadi bahan untuk ditindaklanjuti dan didalami oleh wartawan profesional. Wartawan melakukan riset dan menglengkapi narasumber juga data sehingga berita akan menjadi lebih lengkap dan mendalam.

Selain berperan sebagai citizen journalist, masyarakat menurut Muhammad Rendi (2016), juga bisa berperan sebagai pembaca atau konsumen media. Artinya, masyarakat tidak hanya memberikan tetapi juga mendapatkan berita dari masyarakat yang lain. Di tengah kondisi media maenstream tidak memberikan kepuasan kepada publik, maka disitulah masyarakat tampil untuk saling berbagi informasi dan opini bukan hanya saling memberikan informasi tetapi juga dapat menjadi kontrol sosial.

Civic journalism mengacu kepada berbagai praktek kegiatan berbasis teknologi informasi, di mana pengguna dapat melakukan praktek jurnalistik walaupun mereka bukan wartawan. Jurnalisme warga meliputi praktik seperti blogging, berbagi foto, berbagi videio, dan menyampaikan berbagai informasi yang ada di sekitarnya, bahkan dapat mengomentari tentang berbagai hal yang dekat dengannya (Godge, 2009). ${ }^{18}$

Dengan citizen journalism, warga dapat berpartisipasi dalam proses pemberitaan tanpa harus menjadi wartawan secara formal yang memiliki keterikatan dengan media massa secara langsung. Dengan kata lain, definisi jurnalisme warga tidak memiliki batas yang kaku. Hal ini dimungkinkan untuk mengadopsi definisi jurnalisme warga negara yang relatif sempit atau ketat.

\section{Konsep PR FM Dalam Menjalankan Fungsi Pers \\ Sejarah singkat}

Radio PR FM merupakan salah satu perusahaan media yang ada di Kota Bandung. Radio ini bagian dari grup media terbesar di Jawa barat yaitu Pikiran Rakyat. Sebelum hadir sebagai radio berita, PR FM sebelumnya sudah beberapa kali berganti nama. Sejak bergabung dengan PR grup pada tahun 1989, PR Mustika Parahyangan ini memiliki format sebagai radio wanita, radio dangdut, dan musik daerah. Kemudian akhirnya kembali ke radio wanita dengan brand Radio Mustika.

Pada awal berdirinya, stasiun radio yang disahkan oleh pejabat dari Direktorat Jenderal RTF (Radio Televisi dan Film) Departemen Penerangan ini bernama "Parahyangan Radio". Pada tahun 1981 "Parahyangan Radio" berubah menjadi "Mustika Parahyangan" sesuai dengan nama perusahaannya yaitu PT. Mustika Parahyangan dipimpin oleh Hilman BS dari Pikiran Rakyat.

Untuk lebih memperkuat image Pikiran Rakyat yang identik dengan berita, maka pada 8 Nopember 2009 
radio ini menjadi PR FM dengan berita sebagai pilihan. Sebagai radio berita, PR FM kemudian menerapkan konsep yang lebih maju yaitu civic journalism dengan konsep pelaporan berita berbasis publik yang diambil dari konsep citizen journalism.

Citizen journalism bagi PR FM merupakan tulang punggung dalam pemberitaannya. Hal tersebut diakui yang membuat PRFM memiliki kecepatan mengendus peristiwa yang terjadi di lapangan, tidak tanggung-tanggung, kini PR FM memiliki lebih dari 100 ribu pendengar yang teregistrasi, sekaligus juga mereka sebagai informan berbagai hal terkait dengan kepentingan publik kapan saja, baik pagi, siang, sore, maupun malah hari. Selain itu, dengan konsep citizen jorunalismnya ini PR FM memiliki puluhan ribu audien yang selalu menguatkan salurannya lewat berbagai media sosial seperti twitter@ PRFMnews, facebook PRFM News Channel, instagram PRFMnews, dan line PRFMnews.

Dalam meningkatkan perannya, ada beberapa program unggulan di PRFM, diantaranya ada program harian seperti Citizen Report, Citizen Opinion, Expert Voice, Comprehensive News, Patroli 86, Sport News, Info Cuaca, Traffic Report, Pasar Rupiah dan News Flash. Sementara untuk program mingguan, adalah: Ridwan KamilngaBANDUNGan, Bincang Malam, Gebyar Marketing, Tanya Dokter, Muda Bandung, NgaguarWaris, Sampurasun PKK, Inspirasi Rohani, Inspirasi Pagi, dan Kisah Persib.

Atas kiprahnya membangun partisipasi publik dalam menyehatnya proses demokratisasi di Bandung dan Jawa Barat, PR FM sampai tahun 2015 telah meraih beberapa penghargaan. Seperti: Pemenang KPIDJabar Award kategori Program Berita Radio pada 2010, Juara 1 News Presenter Radio Jawa Barat pada 2011, Juara 3 Nasional dalam Indonesia Radio Award pada 2012, Pememenang KPID Jabar Award kategori Program Berita Radio pada 2013, PemenangFikomUnisba Award 2013, Pememenang KPID Jabar Award kategori Program Berita Radio pada 2014, Pememenang KPID Jabar Award kategori Program Talkshow Radio pada 2014, Piala Gold LayangKencana Award untuk Iklan Radio pada 2014, Piala Silver Layang Kancana Award untuk Iklan Layanan Masyarakat pada 2014, dan Pememenang KPID Jabar Award kategori Program Berita Radio pada 2015.

Semua prestasi yang diraih merupakan buah kerja keras dan pilihan tepat ketika pada tahun 2009 menetapkan sebagai radio yang tegas memilih berita sebagai ciri khasnya. Sejak awal sebenarnya ada beberapa kekhawatiran ketika PR FM menetapkan berada di jalur berita secara total, sebab pilihan ini resikonya harus didukung oleh personil yang lebih banyak dibanding radio berbasis hiburan. Selain itu, diperlukan dana yang besar, sebab untuk melakukan liputan berita dibutuhan anggaran yang cukup banyak. Selebihnya, memang diperlukan proses yang lebih rumit ketika harus sering membuat siaran berita, ketimbang radio hiburan yang terbilang ringan, asalkan banyak stok lagu.

Namun, kehawatiran itu sejak awal sudah diminimalisir dengan mengambil konsep citizen journalism. Ada beberapa keuntungan ketika PR FM akan mengambil konsep citizen jorunalism, pertama, lebih murah. Dikatakan murah, sebab nanti informasi lebih banyak berasal dari masyarakat, bukan wartawan yang mencari secara terus menerus. Kedua, efisien. Dengan melibatkan publik, waktu yang dibutuhkan relatif singkat, sebab publik posisinya tersebar, sehingga sebuah informasi akan lebih cepat didapat, begitu pun dalam proses produksinya. Ketiga, dengan konsep citizen journalism, PR FM akan mendapat kesempatan lebih untuk 
lebih dekat dengan masyarakat, sebab setiap saat masyarakat dapat berinteraksi dengan penyiar.

Walaupun tahun 2009 kajian tentang citizen journalism di tanah air belum begitu populer, namun manajemen PR FM dibantu oleh konsultan dan Wapemred Pikiran Rakyat cetak saat itu melihat ada peluang besar bahwa pilihan itu tidak salah. Pertama, sebenarnya sebelum ada PR FM, di Bandung ada Radio Mara FM yang menggunakan pola citizen journalism, tetapi karena konsepnya mungkin kurang cocok maka kondisinya semakin meredup. Sehingga pada saat itu, Bandung tidak memiliki radio dengan konsep citizen journalism dalam menjalankan fungsi persnya. Kedua, pada saat itu sudah mulai muncul dan menjamurnya media sosial seperti facebook dan black barry (BB). Media sosial ini ditengarai akan semakin mempermudah proses kerja dari citizen journalism, sebab masyarakat dapat berkolaborasi dengan pihak crew PR FM dalam berbagi informasi dan menanggapi setiap kontennya. Sehingga, walaupun awalnya PR FM hanya digawangi oleh lima orang saja, pelan-pelan mendapatkan bentuknya hingga akhirnya mendapat tempat di masyarakat.

Untuk memperkuat PR FM sebagai radio yang menerapkan konsep citizen journalism, maka dibuatlah tagline "Andalah Reporter Kami". Bahkan masyarakat dianggap sebagai pihak yang turut memperkuat saluran PR FM, sebab mereka bukan hanya pendengar tetapi juga turut berbagi informasi. Dalam proses produksi beritanya, informasi yang berasal dari masyarakat kemudian dikembangkan menjadi berita khas radio, kemudian menjadi lengkap, akurat, dan berimbang. Sedangkan posisi redaktur yang berperan sebagai gate keeper di sini harus menindaklanjuti berbagai informasi dari warga kepada narasumber yang berwenang dan kompeten. Bahkan tidak jarang juga penyiar juga membagikan informasi kepada masyarakat lainnya yang dapat memberikan jawaban dari masalah yang disampaikan pendengar lain.

\section{Membangkitkan Minat Berbagi Informasi}

Awalnya tidak mudah untuk mengajak masyarakat berbagi informasi lewat PR FM. Selain pola ini belum biasa bagi masyarakat, juga aspek budaya yang belum terbangun, bagaimana bisa masyarakat dapat memberikan informasi ke radio seperti PR FM. Walaupun pernah ada radio dengan konsep berita di Bandung, tetapi tidak menjadikan masyarakat sebagai reporternya.

Untuk membangun budaya baru, para penyiar PR FM sejak awal sudah memulai mengajak masyarakat untuk berbagi informasi. Setiap hari para penyiar bergantian selalu mengajak masyarakat untuk menjadi bagian dari masyarakat informasi. Masyarakat diajak untuk melaporkan tentang apa saja yang ada di sekitarnya. Seruan itu dianggap realistis sebab saat itu masyarakat bisa menggunakan gedget dan media sosialnya sebagai sarana untuk saling berbagi informasi.

Beberapa minggu berlalu, apa yang menjadi harapan PR FM agar masyarakat dapat berbagi informasi tidak terjadi. Ada yang masuk informasi tapi sangat jarang sekali dan dapat dihitung jari. Melalui sebuah rapat redaksi, maka para penyiar berinisiatif untuk memberikan contoh bagaimana cara melaporkan dari lapangan dengan gaya masyarakat biasa. Maka setiap penyiar akhirnya setiap akan berangkat kerja, kondisi beberapa titik ruas jalannya selalu dilaporkan, termasuk ketika pulang kerja, bahkan ketika berangkat ke manapun. Dengan menggunakan nama samaran, para penyiar bermaksud untuk merangsang agar masyarakat lain mengikuti apa 
yang dicontohkan tersebut. Walaupun menggunakan nama samaran, tetapi setiap penyiar dipastikan membeirkan laporan yang benar, faktual, akurat, dan berimbang.

Dalam sebuah evaluasi, ternyata cara memberikan contoh laporan kepada masyarakat membuahkan hasil. Hanya saja, apa yang terjadi jauh dari harapan yang sesungguhnya. Artinya, PR FM masih menganggap masyarakat masih sangat rendah dalam menginformasikan apa yang ada di sekitarnya, sehingga semua crew kembali mencari jalan bagaimana agar masyarakat mau berbagi informasi.

Crew PR FM saat itu memiliki asumsi bahwa secara umum masyarakat kita lebih suka mengomentari sesuatu ketimbang membagi sesuatu. Maka cara kedua yang diambil adalah dengan memancing masyarakat untuk menanggapi berbagai peristiwa atau berita yang disampaikan oleh penyiar. Cara ini sebagai pancingan agar masyarakat mau masuk menyampaikan opininya terlebih dahulu. Ternyata, pola yang kedua ini jauh lebih sukses, banyak masyarakat yang kemudian menyampaikan tanggapan terhadap berbagai peristiwa, isu, atau berita yang disampaikan. Berkomentar lebih mudah dari pada berbagi informasi ternyata benar-benar terbukti.

Namun, saling memberikan komentar sebenarnya bukan target dari PR FM. Yang diinginkan adalah bagaimana masyarakat memberikan informasi walaupun itu hal kecil dan dianggap bukan peristiwa besar. Kemudian penyiar menggiring setiap orang yang akan memberikan komentar itu dengan pertanyaan-pertanyaan ringan, seperti posisi anda sekarang dimana? Bagaimana kondisi lalu lintas sekitar anda? Bagaimana cuaca di wilayah anda? Adakah hal-hal yang ingin anda sampaikan kepada pendengar lain?

Pertanyaan-pertanyaan kecil dan sangat riangan in i senantiasa disampaikan dan seolah menjadi ritual bagi penyiar terhadap siapapun masyarakat yang akan memberikan komentar. Maka akhirnya, apa yang menjadi kebiasaan ini memberikan dampak luar biasa, dimana publik kemudian menjadi sadar betapa informasi ringan itu dapat membantu orang lain. Selain itu, publik juga mulai tahu bahwa selain menjadi pendengar, kini dirinya juga dapat memberikan kabar seperti halnya reporter atau wartawan.

Tugas selanjutnya bagi crew PR FM adalah memastikan bahwa setiap masyarakat yang membagikan informasinya akan mendapatkan manfaat. Bisa jadi sebagian besar publik yang juga belum mau memberikan informasi adalah ketikatidakadanyadampakyangsignifikan dari informasi yang diberikannya kepada PR FM. Maka di sini, PR FM kemudian melakukan langkah lebih kongkret lagi, yaitu dengan cara membantu masyarakat yang menyampaikan tentang persoalan. Jika ada publik yang bertanya, PR FM selalu berusaha untuk mencari jawabannya. Ketika PR FM tidak mengetahui jawabannya, maka PR FM akan membagikan pertanyaan itu kepada masyarakat yang lain, sehingga nanti ada pendengar PR FM yang rela berbagi informasi untuk menjawab pertanyaan tadi. Kemudian, jika persoalan itu membutuhkan jawaban dan kepastian dari pihak berwenang seperti pemerintah atau pihak yang berwajib, maka PR FM pada saat itu juga langsung meneruskannya, bisa langsung mengontaknya dan on air, atau secara off air mencari kepastian jawaban itu. Maka dapat dipastikan setiap pendengar yang menyampaikan apapun ke PR FM dapat mendapat jawabannya, termasuk hal-hal yang sangat kecil dan personal.

Bentuk lain dari PR FM untuk memancing orang senantiasa memberikan laporannya adalah dengan mengapresiasi seperti menyebutkan nama pelapor. Setiap 
orang yang membagikan informasi sekecil apapun pasti disebut namanya, bahkan sampai berulang-ulang. Penyebutan nama seperti ini bagi masyarakat biasa bisa jadi memberikan semangat untuk kembali berkirim informasi. Penghargaan itu mungkin kecil dan sederhana, tetapi dianggap mampu menyentuh kebutuhan dasar manusia yaitu bahwa setiap manusia ingin dihargai, minimal disebut namanya.

\section{Pola Penguatan Civic Journalism}

Menjadi bagian dari proses demokrasi dapat dilakukan warga negara dengan menjadi pewarta media dengan tanpa terikat dengan media massa. Menguatkan peran masyarakat dalam kehidupan sosial dan politiknya dilakukan PR FM dengan memberikan kesempatan untuk senantiasa bersuara, menyampaikan suaranya, mengabarkan hal-hal kecil di sekitarnya, atau bertanya tentang apa saja termasuk hal pribadi sekalipun.

PR FM memberikan jalan kepada masyarakat dengan memposisikan radionya sebagai jembatan aspirasi. Di sini PR FM akan memberikan kesempatan yang sama kepada siapapun untuk senantiasa melakukan kritik dan saran, memberikan masukan dan kontribusi opini, untuk kebaikan dan kelancaran bersama. Kelancaran dalam bidang kepentingan publik seperti saran infra sturktur jalan, sungai, area publik, hingga dalam mempermudah persoalan masyarakat seperti menemukan orang hilang atau yang hanya sekedar memberi tahu orang yang kebingungan bagaimana cara membuat KTP atau SIM misalnya.

Walaupun tidak secara tiba-tiba, PR FM secara bertahap selalu membimbing dan mengarahkan masyarakat untuk tampil dan aktif agar satu sama lainnya memiliki posisi yang sama. Untuk itu upaya yang dilakukan oleh PR FM tersebut diantaranya:

Pertama, membangkitkan percaya diri publik. Sejak awal, PR FM memberikan peluang dan semangat kepada masyarakat untuk senantiasa berbagi informasi. Bahkan saat ini masyarakat juga dapat berbagi informasi, mengkritisi, dan memberikan solusi secara bebas lewat media, walaupun dirinya bukan wartawan. Dengan pola pancingan agar publik memberikan tanggapan, kemudian dengan pola-pola pertanyaan yang dilontarkan, langsung atau pun tidak memberikan kepercayaan diri bagi masyarakat dalam dunia jurnalisme. PR FM mempoisisikan masyarakat sebagai urat nadinya saluran berita ini, sebab di sini PR FM memposisikan dirinya sebagai jembatan informasi.

Apa yang dilakukan oleh PR FM hanyalah menyalurkan aspirasi, menjawab pertanyaan, melempar pertanyaan kepada sesama publik, atau meneruskan aspirasi dan kritik kepada pihak-pihak yang berwenang. Sebaliknya, kepada pemerintah, PR FM juga tidak menghakimi ketika menyoroti permasalahan tertentu termasuk menyoroti kebijakan. PR FM menganggat persoalan bukan untuk menyudutkan pemerintah tetapi mengingatkan apa yang terjadi di lapangan, sekaligus memberikan ruang yang leluasa kepada pihak yang disoroti untuk memberikan klarifikasi atau jawaban. Berbeda dengan media lain yang lebih menekan kepada pengambil kebijakan, PR FM justru memberi peluang, sehingga diakui oleh PR FM bahwa menghubungi pejabat daerah termasuk menteri-menteri tidak lah sulit - karena mereka tahu kalau PR FM sedang ingin menyelesaikan masalah bukan akan menekan pemerintah.

Kedua, Membangun kepedulian. Untuk menjadi bagian dari masyarakat informasi dengan pola citizen journlism, tidak mungkin dilakukan tanpa adanya kepedulian dari publik. Di sini publik berharap dapat memberikan informasi yang didasarkan pada kepedulian. 
Semakin banyak warga yang peduli maka semakin banyak orang yang mendapat menfaatnya. Akhirnya antar masyarakat satu sama lainnya akan saling menguntungkan. Logikanya, jika kita ingin diberi informasi maka seringseringlah memberikan informasi, jika suka menerima maka harus suka memberi.

Yang menarik di sini, ketika PR FM mencobauntukmembangkitkankesadaran lewat pancingan-pancingan produktif sehingga masyarakat secara suka rela memberikan informasi dan memberikan solusi terhadap persoalan tertentu kepada sesama pendengar. Pada dasarnya setiap orang memiliki kepedulian, sebagai mahluk sosial, tentu saja kepedulian satu orang terhadap lainnya menjadi wajar. Hanya saja, tidak banyak media yang dapat membangkitkan kepedulian masyarakat sekaligus memberikan ruang untuk menyampaikan kepeduliannya itu.

Ketiga, Pemberi kabar sekaligus pemberi solusi. Civic journalism membutuhkan keterlibatan masyarakat seperti halnya memberikan informasi apapun kepada orang lain lewat media massa. Sampai di sini, PR FM selalu mendorong masyarakat sejak awal untuk senantiasa memberikan informasi. Namun, selangkah lebih dari itu, PR FM juga selalu memberikan kesempatan kepada masyarakat untuk senantiasa memberikan solusi terhadap persoalan yang dimiliki orang lain. Pengetahuan masyarakat tentag hal-hal tertentu juga dapat disampaikan dalam rangka memperkuat kemanfaatan dari PR FM yang selalu memberikan jawaban atas pertanyaan publik.

Pemberian solusi dalam konteks ini bukan hanya pada isu-isu yang besar, tetapi juga hal sederhana yang ingin diketahui orang lain, misalnya ada pendengar yang bertanya tentang alamat, bertanya tentang jalan bebas macet, atau bertanya tentang sim keliling dan penjual makanan tertentu. Pertanyaan tersebut sebenarnya bersifat personal, tetapi PR FM memberikan peluang kepada pendengar lainnya untuk memberikan jawaban atau berbagi informasi terhadap apa yang ditanyakan. Dengan cara ini, PR FM tidak memposisikan pihaknya yang paling tahu segalanya, sebab pada kenyataannya masyarakat terkadang lebih tahu, di sinilah sisi demokrasi dapat berjalan dengan sehat.

Keempat, bukan berita adalah berita. PR FM dalam menjalankan perannya sebagai radio berita mampu merekonstruksi makna berita yang sejak dulu sudah mapan. Jika dulu yang disebut berita adalah sesuatu yang jelek, kasus, atau peristiwa negatif. Hal-hal yang sifatnya positif tidak dianggap sebagai berita, maka dikenal adagium "bad news is good news". Maka apa yang disebut berita tidak lain sebuah peristiwa besar dan hal-hal yang bersifat negatif. Di dunia lalu lintas misalnya, kemacetan adalah berita, tetapi jika jalan lancar makan bukan berita. Pada isi seperti ini misalnya, PR FM membuka ruang untuk menciptakan arti baru dari sebuah berita bahwa berita atau informasi tidak selamanya yang sifatnya negatif tetapi juga yang positif atau yang baik-baik. Maka tidak aneh jika mendengar siaran PR FM banyak masyarakat yang mengabarkan tentang jalan yang lengang, tentang cuaca yang cerah, pelayanan publik yang berjalan baik, termasuk hal-hal baik lainnya.

Dalam konteks ini, publik menjadi lebih objektif melihat fenomena sosial tertentu, jika ada yang tidak baik dapat disoroti, tetapi jika ada yang baik juga dapat diapresiasi. Pada kasus lain misalnya, jika ada pendengar yang menyoroti masalah tertentu, kemudian PR FM meneruskannya kepada pihak yang berwenang, kemudian yang berwenang menyelesaikan persoalannya, maka di sini pendengar dapat menginformasikan lagi terhadap persoalan yang sudah selesai dan kondisi menjadi baik. Bisa 
dicontohkan misalnya ketika PJU mati, ada pendengar yang melaporkan ke PR FM, kemudian PR FM melanjutkan kepada yang berwenang, yang berwenang memperbaiki PJU hingga nyala lagi, maka pendengar tadi atau pendengar yang lain dapat melaporkan kembali tentang PJU yang sudah nyala tersebut. Di sini PR FM telah membangun suansa demokrasi yang fair dan berimbang.

Kelima, Konten remeh temeh makin menarik. Bagi PR FM, konten semakin kecil semakin menarik. Pada umumnya media akan semakin merasa sukses jika mampu menyajikan berita yang besar, peristiwa luar biasa, atau ketika mewawancara pejabat tinggi atau orang terkenal. Tetapi berbeda dengan PR FM yang menganggap mewawancarai pejabat negara itu hanyalah selingan semata.

Membangun demokratisasi di tataran akar rumput melalui citizen journalism tidak kemudian harus mengangkat hal-hal besar, tetapi cukup lah publik melaporkan hal-hal sepele tentang segala sesuatu yang ada di sekitarnya pada saat itu pula. Semakin banyak laporann hal-hal kecil yang terjadi di sebuah daerah, maka semakin komprehensif sebuah konten media tersebut. Maka jika di tarik ke atas, hamparan konten yang dianggap remet temeh itu menjadi sebuah potret kota yang sangat lengkap, kemudian setiap orang akan membutuhkan potret itu untuk sekedar mengetahui atau bahkan menjadi guide dalam beraktivitas.

Selain laporan, remeh temeh dalam konten PR FM juga terkait dengan persoalan-persoalan publik. Apa yang ditanyakan pendengar kepara PR FM bukan persoalan politik dan isu-isu yang besar, tetapi menyangkut kepentingan personal, seperti pembuatan KTP, menanyakan lokasi belanja makanan atau pakaian, menanyakan jalan yang akan dilaluinya, atau bahkan melaporkan keluarganya yang hilang. Isu-isu yang sangat personal ini kemudian menjadi kebanggaan PR FM dan dengan senang hati PR FM selalu memberikan jawaban, bahkan turut membantu mencari jawaban kepada pendengar lain jika PR FM pun mengalami kesulitan.

Pada kasus-kasus seperti inilah PR FM mengakui menemukan puncak kepuasannya. Sebab bagi PR FM ketika seseorang semakin melaporkan atau mempertanyakan hal-hal yang bersifat pribadi, itu artinya PR FM sudah dianggap sebagai teman dekat bahkan saudara. Sebab pada dasarnya tidak mungkin seseorang dapat membicarakan hal-hal yang sifatnya pribadi kepada pihak yang tidak dikenal atau kenal tetapi masih jauh. Artinya, ketika pendengar membicarakan hal-hal yang sifatnya pribadi, berarti PR FM dianggap bukan siapa-siapa, dan disitulah kedekatan itu terbangun.

Di alam demokrasi, pembicaraan publik tidak selamanya terkait isu-isu besar, tetapi juga bagaimana publik dapat dengan bebas tanpa beban untuk senantiasa berbagi tentang hal-hal remeh temeh yang sejak dulu dianggap tidak berarti oleh media massa. Dengan difasilitasi oleh PR FM, publik ternyata memiliki hasrat dan kepuasan tersendiri, sehingga tidak sedikit pertanyaan yang sama disampaikan oleh pendengar yang berbeda. Di sini posisi media sekaligus membantu pemerintah atau pengambil kebijakan dalam mensosialisasikan sebuah regulasi tertentu yang jika tanpa media pemerintah akan kesulitan menyampaikannya kepada masyarakat.

\section{Posisi PR FM dalam Civic Journalism}

Jika kita melihat lebih dekat tentang posisi PR FM, maka di tengah perannya dalam membangun iklim demokrasi melalui civic jorunalism, yang menarik kemudian adalah dimana posisi PR FM di tengah riuh rendahnya dunia media massa yang makin menjamur. Bahkan posisi PR FM juga menarik untuk dilihat di tengah 
aktifnya para pendengar dengan tingkat kedekatan yang begitu "intim". Kita dapat melihat posisi PR FM setidaknya pada empat lokasi yang sangat strategis.

Pertama, menjadi tempat curhat. Sebenarnya tidak ada dalam fungsi pers untuk menjadi tempat curhat. Tetapi faktanya, PR FM selama ini menjadi tempat melaporkan hal-hal yang terkait dengan kepentingan publik hingga urusan pribadi. Masalah kriminal, baiknya dilaporkan ke yang berwajib atau polisi, tetapi banyak pendengar yang terlebih dahulu melaporkannya ke PR FM. Bukan hanya dalam konteks menginformasikan tetapi juga curhat tentang apa yang dialaminya. Kemudian, jika ada persoalan sarana dan prasarana yang tidak baik seharusnya dilaporkan kepada dinas atau pihak terkait, tetapi justru disampaikan ke PR FM. Kemudian PR FM lah yang melanjutkannya ke pihak yang berwenang itu. Bahkan ketika ada kehilangan barang sampai kehilangan anggota keluarga, yang pertama diberi tahu PR FM, bukan lapor ke polisi atau ke yang lain. Di sini PR FM kemudian mengabarkan kepada publik untuk turut menyelesaikan masalah satu orang pendengar ini.

Menjadi tempat curhan bisa jadi bukan perkara mudah, sebab PR FM harus dapat memberikan "kepuasan" kepada pendengarnya. Bukan hanya mendengarkan isi curhatannya, tetapi juga turut meringankan beban pendengarnya. Posisi ini berhasil dilakukan PR FM dengan senantiasa mengapresiasi pendengar yang curhat, kemudian menindaklanjuti curhatan pendengar tersebut. Artinya, PR FM tidak pernah mengabaikan pendengar yang curhat walaupun hanya satu orang dan itu urusan pribadi.

Kedua, Menjadi jembatan aktif bagi publik dan pengambil kebijakan. Menjadi jembatan yang aktif berbeda dengan posisi media sebagai sauran. Ketika media menjadi saluran informasi, maka keberadaannya bersifat pasif. Tetapi menjadi jembatan yang aktif, artinya PR FM menjadi tepat untuk menitipkan informasi sekaligus dapat meneruskannya kepada pihak yang berwenang. PR FM tidak membiarkan informasi hanya numpang lewat, tetapi diupayakan untuk senantiasa bermakna. Sebuah informasi akan bermakna jika kehadirannya kemudian ditanggapi dan dijadikan sesuatu yang lebih berharga, seperti menjadikan informasi dari pendengar itu kemudian disalurkan, atau bahkan dijadikan topik bahasan. Bahkan tidak jarang PR FM menjadikan informasi dari pendengar itu kemudian dikembangkan pada isu yang lebih mendasar.

Ambil contoh ketika sekolah tertentu di Kota Bandung selalu jalannya macet karena banyak kendaraan anak sekolah yang parkir berjejer di pinggir jalan, awalnya pendengar hanya melaporkan tentang kondisi jalan yang terganggu. Tetapi laporan itu kemudian dikembangkan oleh PR FM menjadi isu anak-anak belum cukup umur menggunakan kendaraan. Kemudian diskusi menjadi seru sampai ke pendidikan orang tua di rumah, hingga akhirnya muncul adanya orang tua yang berusaha membuat KTP aspal yang dilanjutkan ke SIM aspal, semuana dilakukan agar anak yang belum cukup umur dapat mengendarai motor atau mobil.

Dengan wacana ini, kemudian PR FM meminta penjelasan kepada pihak yang berwenang tentang syarat orang yang boleh megendarai roda dua atau roda empat. Dengan penjelasan pihak berwenang kemudian semua persoalan menjadi clear, kemudian edukasi kepada para orang tua pun terjadi. Dengan menjadi jembatan yang aktif, keluhan jalan macet menjadi sebuah proses edukasi yang produktif bahkan tidak jarang menjadi aksi nyata di lapangan hingga tuntasnya sebauh persoalan.

Ketiga, Mengkoreksi kebijakan 
pemerintah. Sejak dulu pers memiliki fungsi untuk melakukan kritik sosial. Faktanya, banyak negara, atau secara umum pemerintah merasa tabu dengan fungsi yang satu ini. Sedangkan PR FM, fungsi itu tidak digunakan untuk memojokkan pemerintah tetapi memfasilitasi. Ketika PR FM mengangkat sebuah persoalan publik baik infrastruktur atau pun kebijakan yang lain, PR FM tidak menghakimi tetapi masalah itu diangkat untuk dijadikan bahan pembelajaran sekaligus dicarikan solusinya. Solusi dalam perspektif PR FM, tidak selamanya datang dari pemerintah saja, tetapi terkadang justru datang dari masyarakat biasa.

Makanya, ketika sebuah kasus diangkat, dalam prakteknya PR FM selalu meminta masukan masyarakat untuk urun rembug menyampaikan pendapatnya cara menyelesaikan masalah. Jadi kehadiran pendengar dalam diskusi itu bukan untuk menghakimi tetapi saling memberikan kontribusi berdasarkan perspektifnya masing-masing. Maka tidak heran jika dalam pengakuannya, PR FM merasa tidak dimusuhi pemerintah walaupun sering menyoroti kebijakan publik, justru merasa sejajar karena dapat memberikan solusi atas masalahnya dengan cara mengajak pendengar untuk udunan ide dan gagasan.

Di sinilah sebenarnya, bagaimana proses demokrasi itu terbangun, ketika antara pemerintah dan masyarakat benarbenar berada dalam posisi yang sejajar. Semuanya saling membutuhkan dan keduanya dapat saling bertukar fikiran. Dengan posisi PR FM seperti ini maka diyakini bahwa pers sudah berkontribus untuk semakin menyehatkan kehidupan berbangsa dan bernegara.

\section{SIMPULAN}

Sebagai bagian dari grup Pikiran Rakyat, PR FM telah memilih untuk menjadi saluran berita di Kota Bandung.
Dengan jangkauan Bandung Raya dan bekerjasama dengan beberapa radio lain di Jawa Barat, PR FM menerapkan civic journalism. Sedangkan konsep pelaporan beritanya PR FM menggunakan citizen journalism. Hasilnya, PR FM mampu meraih banyak penghargaan atas perannya dan menjadi radio yang sangat dekat dengan masyarakat sehingga mampu menjadikan pendengarnya sekaligus menjadi reporter tidak berbayar dengan jumlah ratusan ribu.

Walaupun tidak mudah, sejak awal PR FM selalu mendorong masyarakat untuk selalu memberikan informasi, hingga PR FM sendiri harus mengarahkan publik yang awalnya tidak biasa berbagi informasi. Upaya ini membuahkan hasil, buktinya kini konten PR FM yang sangat padat informasi berharga dari pagi hingga malam, kebanyakan berasal dari pendengarnya sendiri.

Sedangkan dalam melakukan proses penguatan civic journalism, PR FM mendorong masyarakat untuk senantiasa percaya diri, menenamkan kepedulian untuk senantiasa berbagi. PR FM juga memposisikan diri sejajar dengan masyarakat yang lain, di sana ada edukasi tentang pentingnya memberikan solusi atas persoalan yang ada.

Yang tidak kalah penting dalam membangun iklim demokrasi, PR FM kemudian memposisikan diri sebagai media yang tidak merasa paling tahu. Tetapi juga bukan berarti bahwa PR FM menjadi media yang pasif. Walaupun berada di tengah, PR FM kemudian menjadi pihak yang menyalurkan aspirasi masyarakat, sehingga dipastikan bahwa setiap informasi akan ditindaklanjuti dan setiap pertanyaan akan dijawab. Apa yang dilakukan PR FM memberikan gambaran bahwa pers kini tidak melulu berkutat pada kritik sosial, tetapi bersama-sama dengan masyarakat membangun tatanan sosial yang lebih baik lewat metode udunan berita yang dalam dunia media 
disebut sebagai citizen journalism.

\section{DAFTAR PUSTAKA}

Soegito, Sjamsoe. (1981). Prakata dalam buku "Beberapa Segi Perkembangan Sejarah Pers di Indonesia". Jakarta Kompas.

Hill, David T. (2011). "Pers di Masa Orde Baru”. Jakarta. Buku Obor.

Keith, Michael C. (2000a). "Stasiun Radio: Manajemen". Jakarta. Internews Indonesia.

Keith, Michael C. (2000b). "Stasiun Radio: Pemrograman". Internews Indonesia.

Keith, Michael C. (2000c). "Stasiun Radio: Penjualan dan Pemasaran”. Internews Indonesia.

Keith, Michael C. (2000d). "Stasiun Radio: Promosi". Internews Indonesia.

Creswell, J. W. (2009). "Research Design Qualitative, Quantitative and Mixed Methods Aproaches". California: Sage Publishing.

Rosen, Jay (2001). What Are Journalists For?. Yale University Press. p. 75.

Kurniawan, Moch. Nunung. (2007). "Jurnalisme Warga di Indonesia Prospek dan Tantangannya". Dalam Jurnal Makara, Sosial Huamniora Vol. 11, No. 2 Desember 2007.

Rachmiatie, Atie (2005). "Keberadaan Radio Komunitas Sebagai Eskalasi
Demokratisasi Komunikasi Pada Komunitas Pedesaan di Jawa Barat". Jurnal Mediator Vol. 6 No. 2 Desember 2005.

Pew Center for Civic Journalism. "Doing Civic Journalism," at http://www. pewcenter.org/doingcj/, accessed Dec. 25, 2008.

Glasser, Theodore (1999). The Idea of Public Journalism. Guilford Press. p. 44.

Merritt, Davis (1998). Public Journalism and Public Life. Routledge. pp. 94-95.

Dvorkin, Jeffrey A. (2001). "Can Public Radio Journalism Be Re-Invented?" National Public Radio interview with W. Davis "Buzz" Merritt Jr. (Dec. 30) at http://www.npr.org/yourturn/ ombudsman/2001/010705.html, accessed Dec. 25, 2008

Perry, David K. (2003) Roots of Civic Journalism: Darwin, Dewey, and Mead. Lanham, MD: Rowman and Littlefield.

Kusnadi, Priono (2006). “Citizen Journalism Indonesia: Suatu Wujud dari Demokratisasi di Indonesia. 5-6.

Rendi, Muhammad. (2016). "Pengembangan Sistem Citizen Journalism Berbasis Website Dengan Metode Content Based Filtering". Prosiding Edisi 6 Desember Vol. 2 No. 1. 